\title{
Community Response to Covid-19 Handling in Namorambe District, Deli Serdang Regency
}

\author{
Pindi Patana ${ }^{1}$, Irawati Azhar', Bejo Slamet ${ }^{3}$, Nurdin Sulistiyono ${ }^{1}$, Oding \\ Affandi $^{3}$, Susi Aisyah ${ }^{4}$
}

${ }^{1}$ Department of Forest Resource Conservation, Faculty of Forestry, Universitas Sumatera Utara, Medan, North Sumatra, Indonesia

${ }^{2}$ Department of Forest Products Technology, Faculty of Forestry, Universitas Sumatera Utara, Medan, North Sumatra, Indonesia.

${ }^{3}$ Department of Forest Management, Faculty of Forestry, Universitas Sumatera Utara, Medan, North Sumatra, Indonesia.

${ }^{4}$ Rumah Belajar Kehidupan, Komplek Villa Mutiara Johor 2 Blok J9, Namorambe, Deli Serdang, North

Sumatra, Indonesia.

\begin{abstract}
The spread of the Corona virus or better known as Covid-19 cannot be estimated when it will end. This condition is very concerning, including Indonesia, which has the highest death toll in Southeast Asia. This virus has also spread in North Sumatra including Deli Serdang Regency. One of the biggest challenges in mitigating Covid-19 is building public awareness about the importance of following the Covid19 protocol in carrying out daily activities. Unfortunately, this condition is exacerbated by the low level of public awareness by ignoring health protocols during the pandemic period. It is hoped that the role of universities in educating the public can help prevent the spread of Covid-19 and increase community participation in mitigating efforts to prevent its spread. One of them is through community service activities by utilizing traditional ingredients for health drinks which are held at the Villa Mutiara Johor II Complex and its surroundings, Namorame, Deli Serdang Regency. It conducted by giving paticipants a practise demo directly. All materials also were provided for each. From the quissionare, it showed that respondent still confused about Covid-19 handling, but they realized it influenced their economic households. This socialization gave an awareness how important participants to take care immunity themselves by consuming traditional herbal drink.
\end{abstract}

Keywords: Covid 19, Deli Serdang, Handling, Namorambe, Response

Abstrak. Penyebaran virus Corona atau yang lebih dikenal Covid-19 belum bisa diperkitakan kapan akan berakhir. Kondisi ini sungguh sangat memprihatikan termasuk Indonesia yang memiliki tingkat kematian korban tertinggi di kawasan Asia *Corresponding author at: J1.Tri Dharma Ujung No.1 KampusUSU, Medan, North Sumatra, Indonesia

E-mail address: pindi@usu.ac.id 


\begin{abstract}
Tenggara. Virus ini juga telah telah menyebar di Sumatera Utara termasuk Kabupaten Deli Serdang. Salah satu tantangan terbesar dalam mitigasi Covid-19 adalah membangun kesadaran masyarakat tentang pentingnya mengikuti protokol Covid-19 dalam melaksanakan aktifitas sehari-hari. Sangat disayangkan kondisi ini diperparah oleh masih rendahnya kesadaran masyarakat dengan mengabaikan protokol kesehatan selama masa pandemi. Peran serta perguruan tinggi dalam mengedukasi masyarakat diharapkan dapat membantu upaya pencegahan penyebaran Covid-19 serta meningkatkan partisispasi masyarakat dalam upaya mitigasi pencegahan penyebarannya. Salah satunya adalah melalui kegiatan pengabdian pada masyarakat dengan memanfaatkan bahan-bahan tradisional untuk minuman kesehatan yang diadakan di Komplek Villa Mutiara Johor II dan sekitarnya, Kec. Namorame, Kabupaten Deli Serdang. Kegiatan ini dilakukan dengan dengan memberikan contoh praktek langsung. Semua bahan juga diberikan kepada setiap peserta. Hasil kuisioner menunjukkan bahwa responden masih bingun terkait penanganan covid-19, tetapi mereka menyadari tentang pengaruhnya terhadap ekonomi rumah tangga. Penyuluhan ini memberikan penyadaran tentang pentingnya menjaga imunitas dengan mengkonsumsi minuman herbal tradisional.
\end{abstract}

Kata Kunci: Covid-19, Deli Serdang, Namorambe, Penanganan, Respon

Received 27 November 2020 | Revised 21 January 2021 | Accepted 21 February 2021

\title{
1. Introduction
}

The Corona Virus pandemic or better known as Covid-19 has reached more than 39 million confirmed cases worldwide with a death rate of more than 1 million people [1]. This virus has also spread in North Sumatra including Deli Serdang Regency. There are still many people who have been neglected during this pandemic by continuing their activities outside without Covid-19 protocol. Even though local government has issued policies such as working at home, studying at home and worshiping at home. Public awareness of using masks while being outside or doing social distancing is still very low. This is a real example that we can see recently.

The use of changing terms regarded Covid-19 also sometimes confuses the public. For example, some people also do not understand the different terms ODP (People Under Monitoring), PDP (Patients Under Supervision), OTG (People Without Symptoms). Some of these terms are no longer used in the Covid-19 Handling Task Force.

One of the locations where the Covid-19 spread in North Sumatra is quite high is Deli Serdang Regency which is ranked in 2nd grade after Medan City. Deli Serdang is a strategic location because it is one of the international gateways with the Kualanamu 
International Airport existence. It is feared that the low level of public awareness about Covid-19 has the potential to exacerbate the current pandemic.

The government's ability to reach the lowest strata of society is also very limited in terms of both the number of human resources and source of funds. It is hoped that the role of universities in educating the public can help prevent the spread of Covid-19 through community service activities (PKM). Therefore, the PKM program for lecturers to serve is carried out with the aim of providing counseling about Covid and how to use local resources to make health drinks in order to build a healthy and aware family of Covid-19. The reason for this choice is availability for health drink that can be found easily in daily and affordable price such as lemon and lemongrass.

\section{Method}

This Community Service was held at the Villa Mutiara Johor 2 Complex, Deli Tua Village, Namorambe District, Deli Serdang. This service area is bordered with Medan johor subdistrict which is involved in the Covid-19 red zone in Medan City. The data sources come from primary and secondary data. Primary data comes from respondents who attended community service events. This paper also uses secondary data derived from the Covid19 Task Force report data of North Sumatra Province and Deli Serdang Regency.

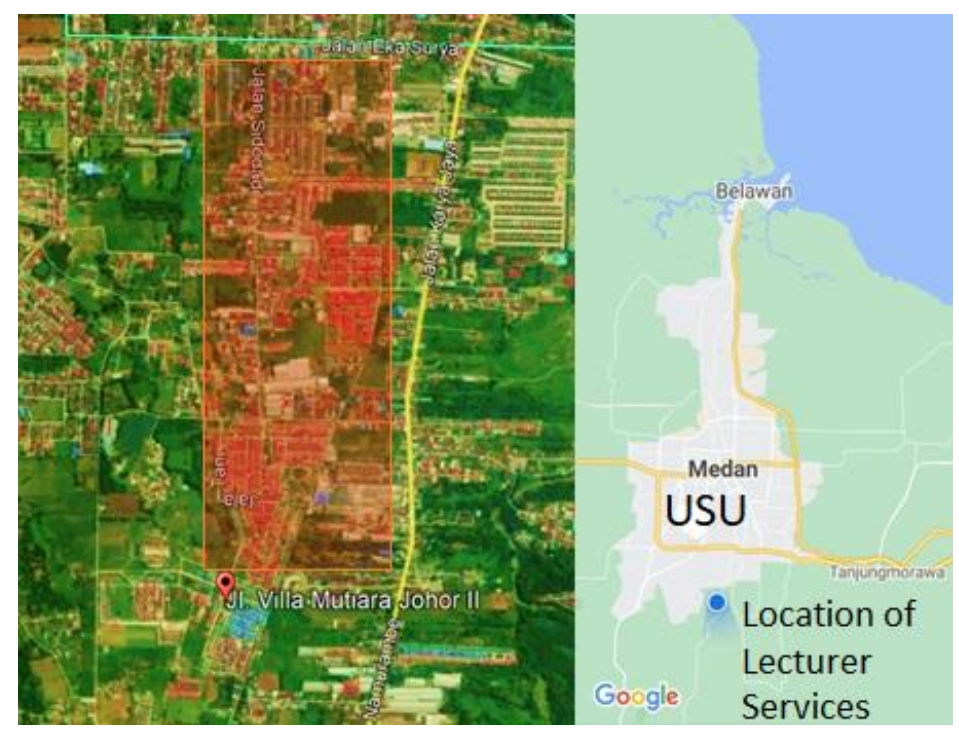

Figure 1. Location of lecturer's community service 2020

The data was collected purposively on residents who were invited to participate in counseling activities and training in making healthy drinks. They come from residents of the Villa Mutiara Johor II complex, Deli Tua Village, Namorambe and residents of Sidodadi, Deli Tua District, Deli Serdang Regency. Data collection techniques were 
carried out by conducting interviews with respondents using a questionnaire. The data analysis for this case study was made descriptively qualitative, as stated [2].

\section{Results and Discussion}

\subsection{Covid-19 Distribution}

North Sumatra Province was in 6th place with 11,861 cases (3.3\%), under DKI Jakarta, East Java, West Java, Central Java and South Sulawesi based on national data on October 17, 2020. Data from the Provincial Covid-19 Task Force also shows the number of Covid19 cases continues to increase even though it's accompanied by the number of recovered patients. Deli Serdang Regency is the second highest area affected by Covid-19 after Medan City. Complete data on the spread of Covid-19 in Deli Serdang is presented in Table 1.

From the overall data obtained, there are only 2 districts out of 33 regencies / cities in North Sumatra where the spread of COVID-19 is not found at all, namely Pakpak Bharat Regency and West Nias Regency. In Deli Serdang Regency, out of 34 sub-districts, there are 5 districts exposed to Covid-19 which are quite severe, namely Bandar Khalifah (10.43\%), Kenangan (9.43\%), Patumbak (7.89\%), Mulyorejo (7.31\%) and Tanjung Morawa (6.74\%). Meanwhile, Deli Tua was in the 8th place $(5.81 \%)$, while Namorambe entered the 10th place (4.41\%). Overall Deli Serdang the number of deaths reached $3.48 \%$, hospitalized (53.51\%), and recovered (40.47\%). The high number of covid in Deli Serdang and many places shows how important cooperation among parties to handle [3].

Table 1. The spread of Covid-19 in Deli Serdang Regency

\begin{tabular}{|c|c|c|c|c|c|c|c|c|}
\hline No & District & Suspect & Hospitalized & Death & Recovery & Total & $\begin{array}{c}\text { Percentage } \\
(\%)\end{array}$ & Rank \\
\hline 1 & Bandar Baru & 0 & 4 & 1 & 2 & 7 & 0.25 & 29 \\
\hline 2 & Tuntungan & 1 & 52 & 2 & 36 & 91 & 3.26 & 13 \\
\hline 3 & Galang & 10 & 15 & 2 & 13 & 40 & 1.43 & 19 \\
\hline 4 & Karang Anyer & 2 & 11 & 1 & 7 & 21 & 0.75 & 24 \\
\hline 5 & Gunung Tinggi & 0 & 54 & 3 & 48 & 105 & 3.76 & 12 \\
\hline 6 & Labuhan Deli & 0 & 41 & 3 & 34 & 78 & 2.80 & 14 \\
\hline 7 & Mulyorejo & 3 & 102 & 7 & 92 & 204 & 7.31 & 4 \\
\hline 8 & Bandar Khalifah & 3 & 160 & 8 & 120 & 291 & $1 ., 43$ & 1 \\
\hline 9 & Batang Kuis & 3 & 34 & 3 & 17 & 57 & 2.04 & 15 \\
\hline 10 & Namo Rambe & 3 & 62 & 5 & 53 & 123 & 4.41 & 10 \\
\hline 11 & Pagar Jati & 1 & 21 & 4 & 16 & 42 & 1.51 & 18 \\
\hline 12 & Dalu X & 0 & 63 & 5 & 46 & 114 & 4.09 & 11 \\
\hline & Sei Mencirim & 0 & 98 & 4 & 67 & 169 & 6.06 & 7 \\
\hline 14 & Tanjung Rejo & 3 & 107 & 4 & 72 & 186 & 6.67 & 6 \\
\hline 15 & Kota Datar & 0 & 16 & 0 & 16 & 32 & 1.15 & 22 \\
\hline 16 & Pematang Johar & 0 & 12 & 1 & 9 & 22 & 0.79 & 23 \\
\hline & Hamparan Perak & 0 & 30 & 3 & 20 & 53 & 1.90 & 16 \\
\hline 18 & Tiga Juhar & 0 & 2 & 0 & 0 & 2 & 0.07 & 32 \\
\hline & Biru-Biru & 0 & 22 & 1 & 12 & 35 & 1.25 & 20 \\
\hline & Talun Kenas & 2 & 5 & 1 & 2 & 10 & 0.36 & 27 \\
\hline
\end{tabular}




\begin{tabular}{lcrrrrrr}
21 Pantai Labu & 1 & 6 & 1 & 4 & 12 & 0.43 & 26 \\
22 Aras Kabu & 3 & 17 & 1 & 13 & 34 & 1.22 & 21 \\
23 Deli Tua & $\mathbf{1}$ & $\mathbf{8 7}$ & $\mathbf{8}$ & $\mathbf{6 6}$ & $\mathbf{1 6 2}$ & $\mathbf{5 . 8 1}$ & $\mathbf{8}$ \\
24 Lubuk Pakam & 12 & 76 & 2 & 57 & 147 & 5.27 & 9 \\
25 Kutalimbaru & 0 & 4 & 0 & 4 & 8 & 0.29 & 28 \\
26 Sei Semayang & 0 & 27 & 1 & 21 & 49 & 1.76 & 17 \\
27 Sibolangit & 0 & 2 & 0 & 2 & 4 & 0.14 & 31 \\
28 Pagar Merbau & 0 & 8 & 0 & 5 & 13 & 0.47 & 25 \\
29 Tanjung Morawa & 18 & 96 & 5 & 69 & 188 & 6.74 & 5 \\
30 Petumbukan & 0 & 0 & 0 & 0 & 0 & 0.00 & 34 \\
31 Gunung Meriah & 0 & 1 & 0 & 1 & 2 & 0.07 & 32 \\
32 Patumbak & 1 & 115 & 11 & 93 & 220 & 7.89 & 3 \\
33 Kenangan & 4 & 140 & 10 & 109 & 263 & 9.43 & 2 \\
34 Bangun Purba & 0 & 3 & 0 & 3 & 6 & 0.22 & 30 \\
\hline \multicolumn{1}{c}{ Total } & $\mathbf{7 1}$ & $\mathbf{1 4 9 3}$ & $\mathbf{9 7}$ & $\mathbf{1 1 2 9}$ & $\mathbf{2 7 9 0}$ & $\mathbf{1 0 0 . 0 0}$ & \\
\hline \multicolumn{1}{c}{ Percentage } & $\mathbf{2 . 5 4}$ & $\mathbf{5 3 . 5 1}$ & $\mathbf{3 . 4 8}$ & $\mathbf{4 0 . 4 7}$ & $\mathbf{1 0 0 . 0 0}$ & & \\
\hline
\end{tabular}

Source: The results of processed real time data of the Covid-19 Deli Serdang Task Force, 17/10/2020

\subsection{Respondent Characteristic}

Participants who attended this counseling activity are limited to only 20 people by implementing the Covid-19 protocol such as wearing masks and maintaining social distancing during the activity. Participants on average were housewives with the most age range between 41-50 years (30\%). Most of them are residents of the VMJ2 complex with their own house status, while $10 \%$ of Sidodadi residents with rental houses. From the income side, $45 \%$ did nott have their own income or only depend on their husbands, but they generally did not mention the figures.

Many families outside the complex still earned below 2 million rupiah. These groups came from local community and mostly have several generation for years and they live like in a cluster family groups. They are among those who are quite affected by pandemic because they mostly work in the informal sector [4]-[6]. The characteristics of the respondent participants are presented in Table 2.

Table 2. Characteristics of outreach and training targets

\begin{tabular}{clcc}
\hline No & \multicolumn{1}{c}{ Characteristic } & Number & Percentage (\%) \\
\hline 1. & Age & & \\
& 20-30 years old & 4 & 20 \\
& 31-40 years old & 3 & 15 \\
& 41-50 years old & 6 & 30 \\
& 51-60 years old & 5 & 25 \\
& > 60 years old & 3 & 15 \\
\hline 2 & House property & & \\
& Self ownership & 18 & 90 \\
& Rent & 2 & 10 \\
\hline 3 & Income of household per & & \\
& month & & 5 \\
& $\leq 1$ milion & 1 & 35 \\
& 1-1,99 milion & 7 & 5 \\
& 2-3,99 milion & 1 &
\end{tabular}




\begin{tabular}{lcc}
$4-4,99$ milion & 1 & 5 \\
$\geq 5$ milion & 1 & 5 \\
Not mention & 9 & 45 \\
\hline
\end{tabular}

\subsection{Public Views on Covid-19 and Its Handling}

The public is sufficient to feel the impact of the Covid-19 pandemic. As many as $85 \%$ of respondents stated that they were very affected economically by the Covid-19 pandemic. People whose income is below 2 million per month are quite heavy to bear the economic burden. Moreover, the covid pandemic also had an impact on the economic crisis [7]. In addition, there are $20 \%$ of respondents who do not have health insurance.

The handling of Covid-19 is still not resolved (70\%). People also still lack health drinks (55\%). However, the community has an awareness of using masks $(75 \%)$ and the habit of washing hands (90\%). Complete interview results can be seen in Table 3.

Table 3. Public views on Covid-19 in Deli Serdang

\begin{tabular}{|c|c|c|}
\hline Element & Frekuensi & Percentage (\%) \\
\hline \multicolumn{3}{|c|}{ The influence of Covid on the economy } \\
\hline Not very influential & 0 & 0.00 \\
\hline Not influential & 1 & 4.90 \\
\hline Little & 2 & 9.80 \\
\hline Very influential & 17 & 85.00 \\
\hline \multicolumn{3}{|l|}{ Insurance Ownership } \\
\hline BPJS & 16 & 80.00 \\
\hline Nothing & 4 & 20.00 \\
\hline \multicolumn{3}{|c|}{ Governmnet effort in handling Covid-19 } \\
\hline Very imperceptible & 11 & 55.00 \\
\hline Not enough & 9 & 45.00 \\
\hline Good & 0 & 0.00 \\
\hline Very good & 0 & 0.00 \\
\hline \multicolumn{3}{|c|}{ The level of satisfaction in handling Covid } \\
\hline Very unsatisfied & 3 & 15.00 \\
\hline Unsatisfied & 3 & 15.00 \\
\hline Satisfied & 14 & 70.00 \\
\hline Very Satisfied & 0 & 0.00 \\
\hline \multicolumn{3}{|l|}{ Habit of drinking health drinks } \\
\hline Yes & 9 & 45.00 \\
\hline No & 11 & 55.00 \\
\hline \multicolumn{3}{|l|}{ Danger level Covid-19 } \\
\hline Understand & 14 & 80.00 \\
\hline Not really understand & 6 & 20.00 \\
\hline \multicolumn{3}{|l|}{ Mask habit out of the house } \\
\hline Always & 15 & 75.00 \\
\hline Sometime & 5 & 25.00 \\
\hline \multicolumn{3}{|l|}{ Habit of washing hand } \\
\hline More frequent & 18 & 90.00 \\
\hline Not really frequent & 2 & 10.00 \\
\hline
\end{tabular}


Public awareness of Covid-19 is really important in early step to prevent the spread of Covid-19. Comparing to research by [8], in relation to two aspects of the Covid-19 outbreak, the respondents had a negative attitude. Firstly $78.6 \%$ respondents having to always maintain a distance of $1.5 \mathrm{~m}$ when in crowds, and secondly $79.1 \%$ respondents not being able to exercise or eat healthy food regularly. Fortunately, they still have good knowledge and attitude regarding the Covid-19 pandemic.

\subsection{Healthy family through traditional beverage processing}

Community counseling was also provided in the form of demonstrations of making healthy drinks made from traditional medicinal plants. The activity was carried out in collaboration with the beverage maker from Rumah Belajar Hidup. The main ingredient of this drink is lemon (Citrus limon). Lemon is one of the ingredients naturally containing high vitamin $\mathrm{C}$ [9]. The materials and materials used in the demonstration are presented in Table 4.

In addition to getting counseling on how to make family health drinks, each participant who attended was also given materials that could be made in their respective homes. The community's response to this activity was very positive and according to them the counseling materials provided were very applicable. From this activity, it hopes they will apply their knowledge in producing healthy drink in their daily to prevent their family from covid-19. In the other hand, they also can practice for selling purposes and generating their income since some of them lose it during pandemic. It's also relevant to government programs that provide microcredit to help community businesses during the pandemic.

Table 4. Material for the production of family healthy drinks

\begin{tabular}{|c|c|c|}
\hline No & Drinking Name & Material \\
\hline 1 & Lemon syrup & Lemon (Citrus limon), white sugar \\
\hline 2 & lemongras drink & $\begin{array}{l}\text { Lemon (Citrus limon), lemongrass (Cymbopogon citratus), white } \\
\text { sugar, water }\end{array}$ \\
\hline 3 & Extracted lemon & Lemon (Citrus limon) \\
\hline 4 & Honey Lime & Lime (Citrus aurantifolia), hot water, honey, salt \\
\hline 5 & Ginger Tea & $\begin{array}{l}\text { Ginger (Zingiber officinale), brown sugar, Spices: cinnamom bark } \\
\text { (Cinnamomum verum), Star anise (Illicium verum), pepper (Piper } \\
\text { nigrum), nutmeg (Myristica fragrans), cloves (Syzygium } \\
\text { aromaticum), cardamom (Amomum compactum), air }\end{array}$ \\
\hline
\end{tabular}




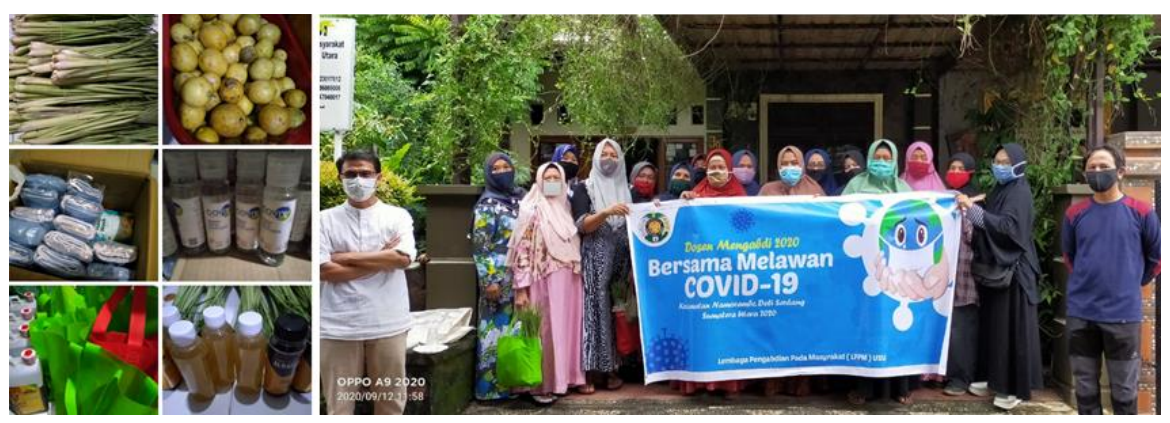

Figure 2. Health drink ingredients and training participants

\section{Conclusions}

Efforts to handle Covid-19 in Namorambe and Deli Tua Districts require socialization efforts and concrete actions to help the community, especially those with low incomes. The risk of vulnerability to Covid-19, not only concerns awareness aspect but also demands economic incentives for people who are directly affected. The handling of Covid-19 that has been running is still not satisfied according to the expectations of the community. The extension of making healthy drink hopefully could encourage community in utilizing traditional manner to strengthen family health during pandemic.

\section{Acknowledgement}

Thanks are conveyed to the management of the complex and residents of the Villa Mutiara Johor II complex as well as the Management of STM Al-Huda and residents of Sidodadi, for participating in this service activity. High appreciation to the Chairperson of the University of North Sumatra Community Service Institution (LPPM) and his staff who provided the opportunity to carry out the service with an agreement letter of assignment to the implementation of community service program schemes for lecturers to serve non-PNBP funding sources USU TA 2020 with work contact Number: 666/UN5.2.3.2.1/PPM/2020.

\section{References}

[1] World Health Organization, "WHO Coronavirus Disease (COVID-19) Dashboard," https://covid19.who.int/(2020) [Accessed on October 5, 2020]

[2] K.J. Colorafi and B. Evans, "Qualitative Descriptive Methods in Health Science Research." Health Environments Research \& Design Journal, 1-11. DOI: 10.1177/1937586715614171 herd.sagepub.com, [online], [Accessed on October 18, 2020]

[3] A.S. Cahyono, "Implementation of the Collaborative Governance Model in Resolving the Covid-19 Pandemic," Publiciana, Vol. 13 No. 1, 2020, http://journal.unita.ac.id/publiciana/index.php/publiciana/article/view/93, (Implementasi Model Collaborative Governance Dalam Penyelesaian Pandemi Covid-19) [Accessed on October 18, 2020].

[4] A.K. Pakpahan, "COVID-19 and Implications for Micro, Small and Medium Enterprises." Faculty of Social and Political Sciences, Parahyangan Catholic 
University, Indonesia, Jurnal Ilmiah Hubungan Internasional, DOI: https://doi.org/10.26593/jihi.v0i0.3870.59-64, 2020, (COVID-19 dan Implikasi Bagi Usaha Mikro, Kecil, dan Menengah). [Accessed on October 18, 2020]

[5] H. Kurniawansyah, A. Amrullah, M. Salahuddin, M. Muslim, and S. Nurhidayati, "Concept of Strategic Policy in Dealing with Economic Externalities from Covid-19 in Vulnerable Communities in Indonesia," Indonesian Journal of Social Sciences and Humanities, 1(2), 130-139, 2020. Retrieved from https://journal.publication-center.com/index.php/ijssh/article/view/117.(Konsep

Kebijakan Strategis Dalam Menangani Eksternalitas Ekonomi dari Covid - 19 Pada Masyarakat Rentan di Indonesia). [Accessed on October 18, 2020]

[6] M. Tapung, M. Regus, M. Payong, S. Rahmat and F. Jelahu, "Social Assistance and Health Education for Coastal Communities Who Are Affected Socio-Economically during the Pathogenesis of Covid-19 in Manggarai." Transformasi: Jurnal Pengabdian Masyarakat, 16(1), 12-26, 2020, doi.org/10.20414/transformasi.v16i1.2067 (Bantuan sosial dan pendidikan kesehatan bagi masyarakat pesisir yang terdampak sosial-ekonomi selama patogenesis Covid-19 di Manggarai). [Accessed on October 18, 2020]

[7] Burhanuddin, Chairul and M. Abdi, "The Global Economic Crisis From the Impact of the Spread of the Corona Virus (COVID-19)." AkMen Jurnal Ilmiah, 17(1), 9098, 2020, https://doi.org/10.37476/akmen.v17i1.866. (Krisis Ekonomi Global Dari Dampak Penyebaran Virus Corona (COVID-19)). [Accessed on October 18, 2020]

[8] D.K. Sari, R. Amelia, and R. Dharmajaya, "Positive Correlation Between General Public Knowledge and Attitudes Regarding COVID-19 Outbreak 1 Month After First Cases Reported in Indonesia," J Community Health. 2020, https://doi.org/10.1007/s10900-020-00866-0. (Korelasi Positif Antara Pengetahuan Masyarakat Umum dan Sikap Tentang Wabah COVID-19 1 Bulan Setelah Kasus Pertama Dilaporkan di Indonesia). [Accessed on October 18, 2020]

[9] I. Anita and A. Yuke, "COVID-19 and Alternative Uses of Vitamins and Herbs," Kopidpedia Article Compilation on Corona Virus Disease (COVID-19). University Publishing Center (P2U) Unisba. Bandung. Hal 76-92, 2020. (COVID19 dan Alternatif Penggunaan Vitamin dan Herba) 